\title{
PENGARUH KEBANGKRUTAN MODEL ALTMAN Z - SCORE TERHADAP HARGA SAHAM PERUSAHAAN MANUFAKTUR YANG TERDAPAT DI BEI PERIODE 2014 - 2016
}

\author{
Noviarti ${ }^{1}$ \\ Program Studi Manajemen Universitas Satya Negara Indonesia \\ noviarti.arif@gmail.com
}

\begin{abstract}
The purpose of this research is to figure out if there is the effect of Altman Z-Score bankruptcy analysis on stock prices at Manufacturing companies listed on the Stock Exchange in the period 2014-2016. The population in this study are all manufacturing companies listed on the Indonesia Stock Exchange (BEI) in 2014-2016 which is 142 companies. Research sample is 42 companies with Purposive Sampling as sampling technique. Hypothesis testing in this research using simple linear regression analysis to test the effect of Z-Score on stock price and multiple linear regression analysis to test variable Altman Z-Score to Stock Price. The results of this study show the partial Z-Score only significant effect on Price Stock. The results also show partially that the variable Altman Z-Socre only Market Value Of Equity To book Value Liabilities significantly influence the Price Stock. And the results of research also show that variable Altman Z-Score is Working Capital To Total Asset, Retained Earning To Total Asset, Earning Before Interest And Taxes To Total Asset, Market Value Of Equity To Book Value Liabilities and Sales To Total Asset simultaneously have an effect on Price Stock.
\end{abstract}

Key words: Altman Z-Score, Working Capital To Total Asset, Retained Earning To Total Asset, Market Value Of Equity To Book Value Liabilities, Sales To Total Asset, Stock Price, Manufacturing Companies.

\section{PENDAHULUAN}

Kondisi ekonomi yang tidak menentu membuat persaingan usaha semakin ketat. Dengan ketatnya persaingan maka berakibat pada meningkatnya perusahaan yang mengalami penurunan kinerja keuangan dan berpotensi mengalami kebangkrutan. Berdasarkan data dari GAIKINDO (Gabungan Industri Kendaraan Motor Indonesia) bahwa pasar domestik dan ekspor-impor sektor industri otomotif pada tahun 2013-2015 terus mengalami penurunan. Pada tahun 2013 total pejualan 1.229.901 unit, kemudian pada tahun 2014 turun menjadi 1.208.028 unit dan pada tahun 2015 turun menjadi 1.013.291 unit.

Kebangkrutan merupakan kondisi dimana perusahaan tidak mampu lagi untuk melunasi kewajibannya. Kondisi ini biasanya tidak datang begitu saja di perusahaan, ada indikasi awal dari perusahaan tersebut yang biasanya dapat dikenali lebih dengan kalau laporan keuangan dianalisis lebih cermat dengan cara tertentu. Rasio keuangan dapat digunakan untuk mengetahui indikasi kebangkrutan di perusahaan. Dengan analisis kebangkrutan dapat memberikan informasi kesehatan keuangan perusahaan bagi manajemen perusahaan untuk melakukan perbaikan sehingga perusahaan terhindar dari kebangkrutan. Sedangkan bagi investor, analisis kebangkrutan dapat digunakan sebagai bahan pertimbangan dalam melakukan investasi disuatu perusahaan sehingga tidak salah memilih saham untuk berinvestasi.

Ada beberapa metode untuk menganalisis kebangkrutan, salah satunya di kemukakan oleh seorang profesor di New York University bernama Edward I Altmant yaitu metode Altman 
$\mathrm{Z}$-score dengan fungsi diskriminan $\mathrm{Z}=1,2 \mathrm{X}_{1}+1,4 \mathrm{X}_{2}+3,3 \mathrm{X}_{3}+0,6 \mathrm{X}_{4}+1,0 \mathrm{X}_{5}$. Jika nilai Zscore lebih besar dari 2,99 maka perusahaan tidak mengalami kesulitan keuangan, kemudian jika nilai Z-score $=1,81-2,99$ maka perusahaan masuk kategori gray area atau rawan banngkrut dan jika nilai Z-score lebih kecil dari 1,81 maka perusahaan mengalami masalah keuangan yang serius atau bangkrut. Jika nilai Z-score perusahaan mengalami penurunan hingga dibawah nilai aman makan hal ini bisa menyebabkan turunnya minat investor terhadap saham perusahaan sehingga harga saham pun bisa ikut turun. Dalam fungsi diskriminan model Altman Z-score terdapat lima rasio keuangan yang digunakan sebagai variabel untuk mendeteksi kebangkrutan perusahaan yaitu Working Capital To Total Asset (WCTA), Retained Earnings To Total Asset (RETA), Earnings Before Interest And Taxes To Total Asset (EBITTA), Market Value Of Equity To Book Value Liabilities (MVEBVL), Sales To Total Asset (STA).

fenomena terjadi pada PT. Pan Brothers Tbk periode 2013-2015 bahwa pada tahun 2013 hingga tahun 2015 nilai Z-score pada PT Pan Brothers mengalami penurunan namun harga saham perusahaan tersebut mengalami kenaikan, hal ini bertentangan dengan teori yang sudah dijelaskan sebelumnya bahwa saat nilai Z-score turun maka harga saham berpotensi turun. Pada tahun 2014 menuju tahun 2015 nilai rasio WCTA pada PT Pan Brothers Tbk mengalami penurunan namun harga saham mengalami kenaikan, hal ini tidak konsisten dengan teori yang sudah dijelaskan sebelumnya bahwa saat rasio WCTA turun maka harga saham berpotensi turun.

Selain itu saat rasio RETA pada PT Pan Brothers Tbk mengalami penurunan pada tahun 2013 menuju 2014 justru harga saham perusahaan itu mengalami kenaikan, hal ini juga tidak konsisten dengan teori yang menjelaskan bahwa pada saat rasio RETA turun maka harga saham akan berpotensi turun.

Kemudian rasio EBITTA pada PT Pan Brothers Tbk mengalami penurunan pada tahun 2013 menuju 2014 justru harga saham pada perusahaan itu mengalami kenaikan, hal ini juga tidak konsisten dengan teori yang menjelaskan bahwa pada saat rasio EBITTA turun maka harga saham akan berpotensi turun.

Rasio MVEBVL pada PT Pan Brothers Tbk mengalami penurunan pada tahun 2014 menuju 2015 justru harga saham pada perusahaan itu mengalami kenaikan, hal ini juga tidak konsisten dengan teori yang menjelaskan bahwa pada saat rasio MVEBVL turun maka harga saham akan berpotensi turun.

Rasio STA pada PT Pan Brothers Tbk mengalami penurunan pada tahun 2013 menuju 2014 justru harga saham pada perusahaan itu mengalami kenaikan, hal ini juga tidak konsisten dengan teori yang menjelaskan bahwa pada saat rasio STA turun maka harga saham akan berpotensi turun.

Beberapa penelitian yang mencoba melihat hubungan pengaruh rasio pembentuk Altman Z-Score terhadap harga saham. Andromeda Ardian (2014) dalam penelitiannya tentang analisis kebangkrutan model Altman terhadap harga saham perusahaan manufaktur yang terdaftar DES periode 2008-2013 menyimpulkan bahwa rasio WCTA berpengaruh signifikan terhadap harga saham perusahaan manufaktur. Dewi sukmawati (2014) dalam penelitiannya juga mengatakan bahwa rasio WCTA berpengaruh signifikan terhadap harga saham. Penelitian yang lain menemukan hasil yang berbeda, Vidya Saputri (2015) dalam penelitiannya menemukan bahwa rasio WCTA tidak berpengaruh terhadap harga saham.

Penelitian sejenis juga memberikan hasil berbeda mengenai rasio RETA terhadap harga saham. Menurut Andromeda Ardian (2014), rasio RETA berpengaruh signifikan terhadap harga saham. Vidya Saputri (2015), rasio RETA berpengaruh signifikan terhadap harga saham. Penelitian lain menurut Dewi Sukmawati (2014), rasio RETA tidak berpengaruh terhadap harga saham.

Penelitian lain, Andromeda Ardian (2014) dalam penelitiannya menyimpulkan bahwa rasio EBITTA berpengaruh signifikann terhadap harga saham. Menurut dewi Sukmawati 
(2014), rasio EBITTA berpengaruh signifikan terhadap harga saham. Penelitian lain menurut Mario Wasono (2012), rasio EBITTA tidak berpengaruh terhadap harga saham.

Penelitian lain, Andromeda Ardian (2014) dalam penelitiannya menyimpulkan bahwa rasio MVEBVL berpengaruh signifikann terhadap harga saham. Menurut dewi Sukmawai (2014), rasio MVEBVL berpengaruh signifikan terhadap harga saham. Penelitian lain menurut Vidya Saputri (2015), rasio MVEBVL tidak berpengaruh terhadap harga saham.

Penelitian lain, Andromeda Ardian (2014) dalam penelitiannya menyimpulkan bahwa rasio STA berpengaruh signifikann terhadap harga saham. Menurut Vidya Saputri (2015), rasio STA berpengaruh signifikan terhadap harga saham. Penelitian lain menurut Dewi Sukmawati (2014), rasio STA tidak berpengaruh terhadap harga saham.

Penelitian lain, Angga Saputra (2013) dalam penelitiannya menyimpulkan bahwa ZScore berpengaruh signifikann terhadap harga saham. Menurut Andromeda Ardian (2014), ZScore berpengaruh signifikan terhadap harga saham. Penelitian lain menurut Kusuma Putra (2016), Z-Score tidak berpengaruh terhadap harga saham.

\section{KERANGKA PEMIKIRAN TEORITIS Harga Saham Pengertian Saham}

Menurut Irham Fahmi (2013:81) pengertian saham adalah tanda bukti penyertaan kepemilikan modal/dan pada suatu perusahaan. Menurut Martalena dan Maya (2011:12), saham (stock) dapat didefinisikan sebagai tanda penyertaan modal seseorang atau pihak (badan usaha) dalam suatu perusahaan atau perseroan terbatas.

\section{Harga saham}

Harga saham merupakan nilai pasar dari selembar saham sebuah perusahaan atau emiten pada waktu tertentu. Harga saham terbentuk dari interaksi kinerja perusahaan dengan situasi pasar yang terjadi di pasar sekunder. Pasar sekunder adalah pasar bagi efek yang telah dicantumkan dibursa. Menurut Agus sartono (2014:70), haraga saham adalah harga pasar saham yang terbentuk melalui mekanisme permintaan dan penawaran di pasar modal.

Nilai suatu saham dapat dipandang dalam empat konsep yang memberikan makna yang berbeda, menurut Sunariyah (2013: 127-128) yaitu:

1. Nilai nominal (par value)

adalah harga saham pertama yang tercantum pada sertifikat badan usaha. Harga saham tersebut merupakan harga yang sudah diotorisasi oleh rapat umum pemegang saham (RUPS). Harga ini tidak berubah-berubah dari yang ditetapkan RUPS.

2. Nilai buku (book value)

Nilai saham akan bermacam-macam dari waktu perusahaan didirikan. Nilai saham tersebut berubah karena adanya kenaikan atau penurunan harga saham dan adanya laba ditahan. Nilai buku untuk setiap lembar saham dihitung dari pembagian jumlah nilai buku dan jumlah lembar saham.

3. Nilai dasar (base price)

Nilai suatu saham sangat berkaitan dengan harga pasar saham yang bersangkutan setelah dilakukan penyesuaian karena corporate action (aksi emiten). Nilai dasar ini merupakan harga perdana saham tersebut. Nilai dasar ini juga digunakan dalam perhitungan indeks harga saham sehingga akan terus berubah jika emiten melakukan corporate action seperti stock split, right issue, dan lain-lain.

4. $\quad$ Nilai pasar (market prices)

Adalah harga suatu saham pada pasar yang sedang berlangsung di bursa efek. Apabila efek telah tutup maka harga pasar adalah harga penutupannya (closing price). Untuk mendapatkan jumlah nilai pasar (market value) suatu saham yaitu dengan mengalikan harga pasar dengan jumlah saham yang dikeluarkan. 


\section{Penilaian harga saham}

Dalam prakteknya penentuan harga saham mengacu pada beberapa pendekatan teori penelitian, dimana dalam perkembangannya parallel dengan persepsi investor yang berniat untuk menanamkan modalnya disuatu perusahaan. Investor akan memperhatikan keadaan keberlangsungan hidup perusahaan penerbit saham (emiten). Investor akan selalu mempertimbangkan resiko usaha sebelum menanamkan modalnya. Menurut jogiyanto (2015:282), terdapat dua model dan teknik analisis dalam penilaian harga saham yaitu:

1. Analisis fundamental

Analisis fundamental bertolak dari anggapan dasar bahwa investor adalah mahluk rasional.

Keputusan investasi saham dari seorang investor yang rasional didahulukan oleh proses analisis terhadap variabel yang secara fundamental diperkirakan akan mempengaruhi harga saham atau efek. Alasan dasarnya jelas yaitu nilai saham mewakili nilai perusahaan tidak hanya itu intrinsik pada sautu saat, tetapi juga kemampuan perusahaan dalam meningkatkan nilainya nilainya untuk jangka panjang.

2. Analisis teknikal

Analisis teknikal menyatakan bahwa investor adalah mahluk yang irasional. Suatu individu yang bergabung kedalam suatu masa, bukan hanya sekedar kehilangan rasionalitasnya tetapi juga seringkali melebur identitas pribadi kedalam indentitas kolektif. Harga pasar saham sebagai komoditas perdagangan dipengaruhi oleh permintaan dan penawaran yang merupakan manifestasi dan kondisi psikologis investor.

\section{Tingkat harga saham}

Tingkat harga saham yang dimaksudkan dalam penelitian ini adalah perubahan harga saham suatu perusahaan yang disebabkan oleh beberapa faktor yaitu diantaranya dikarenakan adanya pengungkapan corporate social responsibility. Perubahan harga saham yang terjadi di pasarjuga merupakan sinyal adanya informasi terbaru (up to date information) yang masuk ke pasar. Informasi tersebut bisa berupa pengumuman emiten terhadap suatu peristiwa seperti pembagian laba, pembagian dividen, merger dan pengungkapan informasi strategi yang dapat menjelaskan posisi terakhir keuangan perusahaan.

Menurut jogiyanto (2015:283), perubahan harga saham merupakan kenaikan penurunan dari harga saham sebagai akibat dari adanya informasi baru yang mempengaruhi harga saham kemudian dibandingkan dengan harga saham tahun lalu. Perubahan harga saham yang bisa dinilai terlalu rendah (undervalued) oleh pasar dan dapat memiliki insentif untuk melakukan penawaran melalui jalur penawaran terbatas (private market), yaitu biaya-biaya informasinya akan lebih rendah. Alternatif ini merupakan salah satu strategi manajer perusahaan untuk melakukan aksi pembelian saham-saham perusahaan yang harganya dinilai rendah atau sering disebut sebagai aksi korporasi yaitu melakukan buy out. Walaupun hal ini tidak bisa dilakukan , kemungkinan hal ini merupakan kendala-kendala yang harus dihadapi oleh para manajer untuk memaksimumkan kesejahteraan mereka pada perusahaan-perusahaan besar. Disamping itu bisa kemungkinan juga dapat timbul masalah inefisien untuk menjual saham-saham perusahaan yang sering dilakukan oleh para manajer karena alasan adanya pemerataan resiko (risk-sharing).

Pada umumnya argumentasi yang menyatakan bahwa manajer-manajer perusahaan yang sahamnya dinilai tinggi (overvalued) cenderung kurang tertarik dan tidak concern dengan informasi-informasi baru (pengumuman bursa) dari pada manajer-manajer perusahaan yang harga sahamnya dinilai rendah (undervalued). Hal ini terjadi karena manajer-manajer perusahaan yang harga sahamnya dinilai tinggi tidak mampu memberi pengungkapan inforomasi yang lebih relevan kepada investor-investor. Apabila harga sahamnya dinilai tinggi, maka para manajer perusahaan mendapat peluang untuk melakukan aksi jual saham yang dipegangnya atau mengeluarkan ekuitas saham baru pada tingkat rate yang favorable. Pada akhirnya pasar akan melakukan koreksi secara otomatis terhadap harga-harga saham yang dinilai terlalu rendah atau terlalu tingggi sehingga tercapai keseimbangan harga saham pasar. 


\section{Faktor-faktor yang mempengaruhi harga saham}

Harga saham selalu berubah setiap harinya, bahkan tiap detik pun harga saham dapat berubah. Menurut Jogiyanto (2015:282) , perubahan harga saham merupakan kenaikan penurunan dari harga saham sebagai akibat dari adanya informasi baru mengenai harga saham kemudian dibandingkan dengan harga saham tahun lalu.

Oleh karena itu investor harus memperhatikan faktor-faktor yang mempengaruhi harga saham. Faktor-faktor yang mempengaruhi fluktuasi harga saham dapat berasal dari internal maupun eksternal. Adapun faktornya internalnya:

1. Laba perusahaan

2. Pertumbuhan aktiva tahunan

3. Likuidasi

4. Nilai kekayaan total

5. Penjualan

Sedangkan faktor eksternalnya adalah:

1. Kebijakan pemerintah dan dampaknya

2. Pergerakan suku bunga

3. Fluktuasi nilai tukar mata uang

4. Rumor dan sentiment pasar

Irham Fahmi (2013:87) mengemukakan bahwa, ada beberapa kondisi dan situasi yang menentukan suatu saham itu mengalami fluktuasi yaitu:

1. Kondisi mikro dan makro ekonomi

2. Kebijakan perusahaan dalam memutuskan untuk ekspansi (perluasan usaha) seperti membuka kantor cabang, kantor cabang pembantu baik yang dibuka di domestik maupun luar negeri

3. Pergantian direksi secara tiba-tiba

4. Adanya direksi atau pihak komisaris perusahaan yang terlibat tindak pidana dan kasusnya sudah masuk pengadilan

5. Kinerja perusahaan yang terus menerus mengalami penurunan dalam setiap waktunya.

6. Resiko sistematis yaitu suatu bentuk resiko yang terjadi secara menyeluruh dan telah ikut menyebabkan perusahaan ikut terlibat.

7. Efek dari psikologi pasar yang ternyata mampu menekan kondisi teknikal jaul beli saham.

2.1. Faktor-faktor yang menentukan perubahan harga saham sangat beragam, namun yang paling utama adalah kekuatan pasar itu sendiri yaitu permintaan dan penawaran akan saham itu sendiri. Sesuai dengan hukum ekonomi, semakin tinggi permintaan akan saham tersebut maka harga saham akan naik. Konsep Kebangkrutan

\section{Konsep Kebangkrutan Dalam Financial Distress}

Financial distress adalah suatu konsep luas yang terdiri dari beberapa situasi, dimana suatu perusahaan menghadapi masalah kesulitan keuangan. Istilah umum untuk menggambarkan situasi tersebut adalah kegagalan, ketidakmampuan melunasi hutang, dan default. Insolvency dalam kebangkrutan menunjukan kekayaan bersih negative. Ketidakmampuan melunasi hutang menunjukan kinerja negative dan menunjukan adanya masalah likuiditas. Default berarti suatu perusahaan melanggar perjanjian dengan kreditur dan dapat menyebabkan tindakkan hukum.

Khaira Amalia Fachrudin (2011) mengelompokan penyebab-penyebab kesulitan keuangan sebagai berikut:

1. Neoclassical model, kebangkrutan terjadi jika alokasi sumber daya tidak tepat. Prediksi kesulitan keuangan dilakukan menggunakan data neraca dan laporan laba rugi. Misalnya ukuran profitabilitas berupa return on assets dan ukuran solvabilitas berupa debt to assets ratio.

2. Financial model, bauran aktiva benar tapi struktur keuangan salah dan dihadapkan pada batasan likuiditas. Hal ini berarti bahwa walaupun perusahaan dapat bertahan hidup dalam 
jangka panjang tapi ia harus bangkrut juga dalam jangka pendek. Hubungan dengan pasar modal yang tidak sempurna dan struktur modal yang menurun menjadi pemicu utama kasus ini. Prediksi kesulitan keuangan dilakukan dengan menggunakan indikator keuangan atau indikator kinerja seperti turnover/total assets, revenues/turnover, ROA, ROE, dan profit margin.

3. Corporate governance model, kebangkrutan disebabkan bauran aktiva dan struktur keuangan yang benar tapi dikelola dengan buruk. Ketidakefisienan ini mendorong perusahaan menjadi out of the market sebagai konsekuensi dari masalah dalam tata kelola perusahaan yang tak terpecahkan. Prediksi kesulitan keuangan dilakukan dengan menggunakan informasi kepemilikan. Kepemilikan berhubungan dengan struktur tata kelola perusahaan dan goodwill perusahaan.

Akibat yang ditimbulkan dari kesulitan keuangan menurut Khaira Amalia Fachrudin (2011) sebagai berikut:

1. Resiko biaya kesulitan keuangan mempunyai dampak negatif terhadap nilai perusahaan yang mengoffset nilai pembebasan pajak (tax relief) atas peningkatan level hutang.

2. Jika manajer perusahaan menghindarkan likuidasi ketika terjadi kesulitan keuangan, hubungannya dengan supplier, pelanggan, pekerja, dan kreditor menjadi rusak parah.

3. Supplier penyedia barang dan jasa secara kredit mungkin lebih berhati-hati atau bahkan mengehentikan pasokan sama sekali, jika mereka yakin tidak ada kesempatan peningkatan perusahaan dalam beberapa bulan terakhir.

4. Pelanggan mungkin mengembangkan hubungan dengan supplier mereka, dan merencanakan sendiri produksi mereka dengan harapan ada keberlanjutan dari hubungan tersebut. Adanya keraguan tentang kelangsungan hidup perusahaan tidak menjamin kontrak yang baik. Pelanggan umunya menginginkan jaminan bahwa perusahaan cukup stabil untuk menepati janji.

Dari urutan diatas dapat disimpulkan bahwa kesulitan keuangan dapat ditinjau dari komposisi neraca yaitu perbandingan aktiva dan kewajiban, dari laporan laba rugi jika perusahaan terus menerus rugi, dan dari laporan arus kas jika arus kas masuk lebih kecil dari arus kas keluar. Sedangkan teori resiko kredit yang dipaparkan dapat diartikan bahwa kegagalan berhubungan dengan struktur modal dan struktur modal berkaitan dengan kondisi ekonomi.

\section{Kebangkrutan}

Bangkrut dapat didefinisikan sebagai suatu keadaan dimana perusahaan berada dalam keadaan insolvensi, ia tidak mampu melunasi kewajibannya dengan sumber daya yang dimilikinya, yang dinyatakan pailit sesuai dengan yang berlaku. Sedangkan kebangkrutan atau kepailitan didefinisikan sebagai suatu prosedur yuridis untuk melikuidasi secara resmi kegiatan suatu perusahaan yang dilaksanakan dibawah pengadilan. Menurut Toto Prihadi (2011:32), kebangkrutan merupakan kondisi dimana perusahaan tidak mampu lagi untuk melunasi kewajibannya.

Berdasarkan pendapat para ahli tersebut, kebangkrutan dapat disimpulkan sebagai suatu keadaan atau situasi dalam hal ini perusahaan gagal tidak mampu lagi memenuhi kewajibankewajibannya karena perusahaan mengalami kekurangan atau ketidakcukupan dan untuk menjalankan atau melanjutkan usahanya sehingga tujuan ekonomi yang ingin dicapai oleh perusahaan tidak dapat dicapai, yaitu profit karena laba yang diperoleh perusahaan dapat digunakan untuk mengembalikan pinjaman, membiayai operasi perusahaan dan kewajibankewajiban yang harus dipenuhi bisa ditutup dengan laba atau aktiva yang dimiliki.

\section{Penyebab kebangkrutan}

Darsono dan Ashari (2010:104) mendeskripsikan bahwa secara garis besar penyebab kebangkrutan bisa dibagi menjadi dua yaitu faktor internal dan eksternal. 
1. Faktor internal adalah faktor yang berasal dari bagian internal manajemen perusahaan. Sedangkan faktor eksternal bisa berasal dari faktor luar yang berhubungan langsung dengan operasi perusahaan atau faktor perekonomian secara makro.

Faktor internal yang bisa menyebabkan kebangkrutan perusahaan menurut Darsono dan Ashari (2010:102) meliputi:

1) Manajemen yang tidak efisien akan mengakibatkan kerugian terus menerus yang pada akhirnya menyebabkan perusahaan tidak dapat membayar kewajibannya. Ketidakefisienan ini diakibatkan oleh pemborosan dalam biaya, kurangnya keterampilan dan keahlian manajemen.

2) Ketidakseimbangan dalam modal yang dimilki dengan jumah hutang-piutang yang dimiliki. Hutang yang terlalu besar akan mengakibatkan biaya bunga yang besar sehingga memperkecil laba bahkan bisa menyebabkan kerugian karena aktiva yang menganggur terlalu banyak sehingga tidak menghasilkan pendapatan.

3) Moral hazard oleh manajemen. Kecurangan yang dilakukan oleh manajemen perusahaan bisa mengakibatkan kebangkrutan. Kecurangan ini mengakibatkan kerugian bagi perusahaan yang pada akhirnya membangkrutkan perusahaan. Kecurangan ini bisa membentuk manajemen yang korup ataupun memberikan informasi yang salah pada pemegang saham atau investor.

2. Faktor eksternal yang bisa mengakibatkan kebangkrutan berasal dari faktor yang berhubungan langsung dengan perusahaan meliputi pelanggan, supplier, debitur, kreditur, pesaing ataupun dari pemerintah. Sedangkan faktor yang tidak berhubungan langsung dengan perusahaan meliputi kondisi perekonomian secara makro ataupun faktor persaingan global. Menurut Darsono dan Ashari (2010:103) faktor-faktor eksternal yang bisa mengakibatkan kebangkrutan adalah:

1. Perubahan dalam keinginan pelanggan yang tidak diantisipasi oleh perusahaan yang mengakibatkan pelanggan lari sehingga terjadi penurunan dalam pendapatan. Untuk menjaga hal tersebut perusahaan harus selalu mengantisipasi kebutuhan pelanggan dengan menciptakan produk yang sesuai dengan kebutuhan pelangggan.

2. Kesulitan bahan baku karena supplier tidak dapat memasok lagi kebutuhan bahan baku yang digunakan untuk produksi. Untuk mengantisipasi hal tersebut perusahaan harus selalu menjalin hubungan baik dengan supplier dan tidak manggantungkan kebutuhan bahan baku pada satu pemasok sehingga resiko kekurangan bahan baku bisa diatasi.

3. Faktor debitur juga harus diantisipasi untuk menjaga agar debitur tidak melakukan kecurangan dengan mengemplang hutang. Terlalu banyak piutang yang diberikan pada debitur dengan jangka waktu pengembalian yang lama akan mengakibatkan banyak aktiva yang menganggur yang tidak memberikan penghasilan sehingga mengakibatkan kerugian yang besar bagi perusahaan. Untuk mengantisipasi hal tersebut, peusahaan harus selalu memonitor piutang yang dimilki dan keadaan debitur supaya bisa melakukan perlindungan diri terhadap aktiva perusahaan.

4. Hubungan yang tidak harmonis dengan debitur juga bisa fatal terhadap kelangsungan hidup perusahaan. Apalagi undang-undang No. 4 tahun 1998, kreditur bisa mempailitkan perusahaan. Untuk mengantisipasi hal tersebut, perusahaan harus bisa mengelola hutangnya dengan baik dengan kreditur.

5. Persaingan bisnis yang semakin ketat menuntut perusahaan agar selalu memperbaiki diri sehingga bisa bersaing dengan perusahaan lain dalam memenuhi kebutuhan pelanggan. Semakin ketatnya persaingan menuntut perusahaan agar selalu memperbaiki produk yang dihasilkan, memberikan nilai tambah yang lebih bagi pelanggan.

6. Kondisi perekonomian secara global juga harus selalu diantisipasi oleh perusahaan. Dengan semakin terpadunya perekonomian dengan negara-negara lain, perkembangan perekonomian global juga harus diantisipasi oleh perusahaan. 
Berdasarkan teori yang dikemukakan diatas maka faktor penyebab kebangkrutan adalah faktor Variabel-variabel dalam Altman Z-score. Variabel-variabel yang digunakan dalam model Altman Z-score (The Jurnal Of Finance, 1968) adalah:

\section{Working capital to total asset (WCTA)}

Rasio ini menunjukan kemampuan perusahaan untuk menhasilkan modal kerja bersih dari keseluruhan total aktiva yang dimilikinya. Rasio ini dihitung dengan membagi modal kerja bersih dengan total aktiva. Jika rasio WCTA semakin rendah maka kemampuan perusahaan untuk memperoleh laba dan likuiditasnya menurun. Hal ini akan dihindari para investor untuk berinvestasi diaham perusahaan. Maka kesimpulan yang didapat yaitu semakin rendah rasio WCTA bisa berakibat menurunnya minat para investor untuk membeli saham perusahaan. Turunya minat investor terhadap saham perusahaan maka mengakibatkan turunya permintaan akan saham perusahaan sehingga harga saham berpotensi turun. Hal ini menunjukkan WCTA memilki hubungan positif terhadap harga saham.

2. Retained earning to total asset (RETA)

Rasio ini menunjukan kemampuan perusahaan untuk menghasilkan laba ditahan dari total aktiva perusahaan. Laba ditahan merupakan laba yang tidak dibagikan kepada pemagang saham. Rasio ini dihitung dengan membagi saldo laba ditahan dengan total aktiva.

Jika saldo laba ditahan turun maka perusahaan harus menambah sumber modal lain untuk memenuhi kebutuhan operasional perusahan dan kemungkinan akan menimbulkan cost of capital atau biaya modal. Hal ini akan mengakibatkan potensi laba bersih yang diporeh perusahaan akan turun karena bertambahnya beban biaya modal sehingga minat investor akan saham perusahaan juga turun. Maka kesimpulan yang didapat yaitu semakin rendah RETA semakin rendah minat investor akan saham perusahaan sehingga rendah permintaan akan saham perusahaan dan harga saham berpotensi turun. Hal ini menunjukkan bahwa RETA memiliki hubungan yang positif terhadap harga saham.

3. Earning before interest and taxes to total asset (EBITTA)

Rasio ini menunjukkan kemampuan perusahaan untuk menghasilkan laba dari aktiva perusahaan sebelum pembayaran bunga dan pajak atau laba operasi. Rasio dihitung dengan membagi laba operasi dengan total asset.

Jika rasio EBITTA turun maka laba bersih juga berpotensi turun hal ini akan membuat minat para investor terhadap saham perusahaan turun kemudian mengakibatkan turunnya permintaan akan saham perusahaan sehingga harga saham berpotensi turun. Maka kesimpulan yang didapat yaitu semakin renda rasio EBITTA maka akan semakin rendah pula permintaan akan saham perusahaan sehingga harga saham berpotensi turun. Hal ini menunjukkan bahwa EBITTA memiliki hubungan positif dengan harga saham.

4. Market value equity to book value of total liabilities (MVEBVL)

Rasio ini menunjukan kemampuan perusahaan memenuhi kewajiban-kewajibannya dari nilai pasar modal sendiri (saham biasa). Nilai modal sendiri diperoleh dengan mengalikan jumlah saham yang beredar dengan harga saham per lembar saham biasa. Rasio ini dihitung dengan membagi nilai pasar saham dengan nilai buku total hutang perusahaan.

Jika rasio MVEBVL turun berarti nilai pasar saham turun atau ada kenaikan pada total hutang perusahaan. Meningkatnya total hutang perusahaan maka akan membuat beban bunga meningkat sehingga potensi laba yang diperoleh menurun. Hal ini akan membuat minat para investor turun terhadap saham perusahaan kemudian permintaan saham perusahaan pun ikut turun dan harga saham perusahaan juga bisa turun. Maka kesimpulan yang didapat yaitu semakin rendah rasio MVEBVL maka akan semakin rendah permintaan saham dan harga saham bisa turun. Hal ini menunjukkan bahwa MVEBVL memiliki hubungan positif dengan harga saham. 


\section{Sales to total asset (STA)}

Rasio ini menunjukkan apakah perusahaan menghasilkan volume bisnis yang cukup dibandingkan investasi dalam total aktivanya. Rasio ini dihitung dengan membagi total penjualan bersih dengan total asset perusahaan.

Jika rasio STA turun berarti pencapaian penjualan perusahaan menurun maka laba bersih berpotensi menurun. Hal ini bisa membuat minat para investor terhadap saham perusahaan menurun kemudian permintaan akan saham perusahaan pun turun sehingga harga saham bisa turun. Maka kesimpulan yang didapat yaitu semakin rendah rasio STA maka semakin rendah permintaan akan saham perusahaan dan harga saham bisa turun. Hal ini menunjukkan bahwa STA memilki hubungan positif terhadap harga saham.

Berikut ini kerangka pemikiran yang disajikan dalam bentuk gambar 1.1:

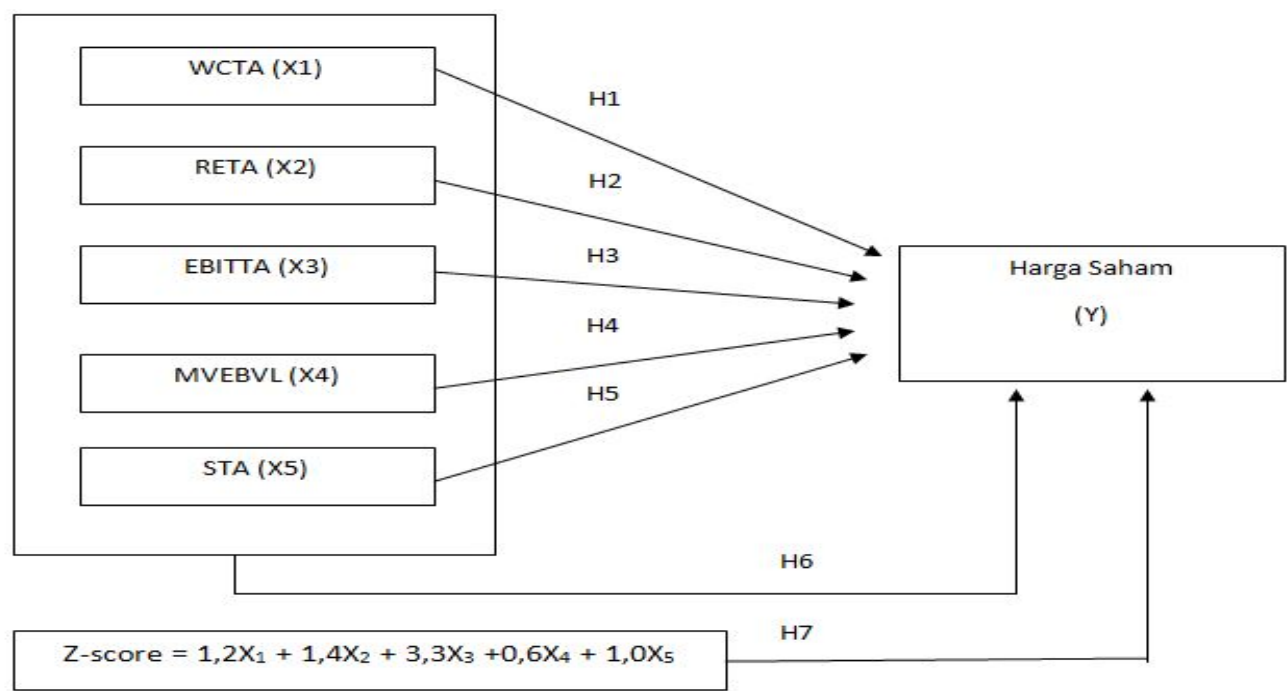

\section{Gambar 1.1 kerangka pemikiran}

Untuk menguji ada atau tidaknya pengaruh dari variabel bebas secara individu atau parsial terhadap variabel terikat maka dilakukan uji t. Hipotesis yang diuji dalam penelitian ini yaitu:

Ha1 = WCTA berpengaruh terhadap harga saham

$\mathrm{Ha} 2=$ RETA berpengaruh terhadap harga saham

Ha3 = EBITTA berpengaruh terhadap harga saham

Ha4 = MVEBVL berpengaruh terhadap harga saham

Ha5 = STA berpengaruh terhadap harga saham

$\mathrm{Ha} 7=\mathrm{Z}$-Score berpengaruh terhadap harga saham.

Untuk menguji ada atau tidaknya pengaruh dari variabel bebas pembentuk Altman Z-Score secara bersama atau simultan terhadap variabel terikat maka dilakukan uji F. Hipotesis yang diuji dalam penelitian ini yaitu: berpengaruh

Ha6 = WCTA, RETA, EBITTA, MVEBVL dan STA secara simultan terhadap harga saham. 


\section{METODE PENELITIAN}

Peneliti data yang digunakan dalam penelitian adalah data sekunder. Data diperoleh dari laporan keuangan tahunan perusahaan manufaktur. Populasi dalam penelitian ini adalah seluruh perusahaan manufaktur yang terdaftar di BEI periode 2014-2016 sejumlah 420 perusahaan. Teknik sampling menggunakan metode purposive sampling dengan kriteria sebagai berikut:

\section{Tabel 4.1}

Tahapan Seleksi Sampel Dengan Kriteria

\begin{tabular}{|l|c|}
\hline \multicolumn{1}{|c|}{ Kriteria Sampel } & Jumlah Perusahaan \\
\hline $\begin{array}{l}\text { Jumlah perusahaan manufaktur yang terdaftar di } \\
\text { Bursa Efek Indonesia 2014-2016 }\end{array}$ & 420 \\
\hline $\begin{array}{l}\text { Jumlah perusahaan manufaktur yang tidak } \\
\text { memiliki laporan keuangan dan data yang } \\
\text { lengkap untuk penelitian }\end{array}$ & 78 \\
\hline $\begin{array}{l}\text { Total Perusahaan manufaktur yang menjadi } \\
\text { populasi penelitian }\end{array}$ & 342 \\
\hline
\end{tabular}

Sumber : Diolah Penulis

Metode analisis yang digunakan adalah analisis deskriptif, analisis regresi linier berganda dan sederhana. Sebelum melakukan analisis regresi linier berganda dan sederhana terlebih dahulu dilakukan uji asumsi klasik ( uji normalitas, uji multikolinieritas, uji heterokedastisitas dan uji autokorelasi).

Pengujian hipotesis menggunakan uji $\mathrm{F}$ untuk menguji pengaruh rasio keuangan pembentuk Altman Z-Score secara simultan terhadap harga saham. Uji t digunakan untuk menguji rasio keuangan pembentuk Altman Z-Score dan Z-Score secara parsial terhadap harga saham. Koefisien determinasi $\left(\mathrm{R}^{2}\right)$ digunakan untuk mengukur seberapa besar pengaruh rasio pembentuk Altman Z-Score dan Z-Score terhadap harga saham.

\section{HASIL DAN PEMBAHASAN}

Sebelum melakukan pengujian hipotesis, dilakukan pengujian asumsi klasik terlebih dahulu. Pengujian asumsi klasik dilakukan 2 kali yaitu untuk regresi linier berganda dan regresi linier sederhana. Dari 342 observasi sebanyak 269 observasi dikeluarkan dari pengamatan karena ada data yang memiliki nilai terlalu tinggi atau terlalu rendah (ekstrim) sehingga yang menjadi sampel dalam penelitian ini berjumlah 42 .

1) Uji Asumsi Klasik Regresi Linier Berganda

a. Uji Normalitas

Tabel 1

Tests of Normality

\begin{tabular}{|l|r|r|r|r|r|r|}
\hline & \multicolumn{3}{|c|}{ Kolmogorov-Smirnov } & \multicolumn{3}{c|}{ Shapiro-Wilk } \\
\cline { 2 - 7 } & Statistic & Df & \multicolumn{1}{c|}{ Sig. } & Statistic & \multicolumn{1}{c|}{ Df } & Sig. \\
\hline WCTA & .100 & 42 & $.200^{*}$ & .941 & 42 & .031 \\
RETA & .132 & 42 & .065 & .923 & 42 & .007 \\
EBITTA & .124 & 42 & .106 & .935 & 42 & .020 \\
MVE_BVL & .120 & 42 & .136 & .923 & 42 & .008 \\
STA & .131 & 42 & .068 & .956 & 42 & .103 \\
Harga_Saham & .116 & 42 & .181 & .941 & 42 & .031 \\
\hline
\end{tabular}

*. This is a lower bound of the true significance.

a. Lilliefors Significance Correction 
Dari hasil output tabel 1 diketahui bahwa semua rasio pembentuk Altman ZScore dan harga saham memiliki nilai signifikansi $>0,05$ maka data tersebut berdistribusi normal.

b. Uji Multikolinieritas

Tabel 2

\begin{tabular}{|c|c|c|c|c|c|c|c|c|}
\hline \multicolumn{9}{|c|}{ Coefficients $^{\mathrm{a}}$} \\
\hline \multirow{2}{*}{\multicolumn{2}{|c|}{ Model }} & \multicolumn{2}{|c|}{$\begin{array}{c}\text { Unstandardized } \\
\text { Coefficients }\end{array}$} & \multirow{2}{*}{$\begin{array}{c}\text { Standardized } \\
\text { Coefficients }\end{array}$} & \multirow[b]{2}{*}{$\mathrm{t}$} & \multirow[b]{2}{*}{ Sig. } & \multicolumn{2}{|c|}{$\begin{array}{l}\text { Collinearity } \\
\text { Statistics }\end{array}$} \\
\hline & & $\mathrm{B}$ & Std. Error & & & & Tolerance & VIF \\
\hline \multirow[t]{6}{*}{1} & (Constant) & 5.945 & .454 & & 13.090 & .000 & & \\
\hline & WCTA & .649 & .645 & .166 & 1.007 & .321 & .690 & 1.448 \\
\hline & RETA & .715 & .537 & .231 & 1.333 & 191 & .624 & 1.602 \\
\hline & EBITTA & 2.135 & 1.638 & .209 & 1.303 & .201 & .729 & 1.372 \\
\hline & MVE_BVL & -1.562 & .728 & -.310 & -2.146 & .039 & .899 & 1.113 \\
\hline & STA & .124 & .351 & .052 & .353 & .726 & .867 & 1.154 \\
\hline
\end{tabular}

a. Dependent Variable: Harga_Saham

Dari tabel 2 diatas dapat diketahui bahwa nilai Variance Inflaction Factor (VIF) dari kelima variabel, yaitu Working Capital To Total Asset, Retained Earning To Total Asset, Earning Before Interest And Taxes, Market Value Of Equity To Book Value Liabilities, dan Sales To Total Asset adalah kurang dari 10 dan nilai tolerance diatas 0.10 sehingga dapat disimpulkan bahwa antar variabel Working Capital To Total Asset, Retained Earning To Total Asset, Earning Before Interest And Taxes, Market Value Of Equity To Book Value Liabilities, dan Sales To Total Asset tidak terjadi persoalan multikolinieritas.

c. Uji Heteroskedastisitas

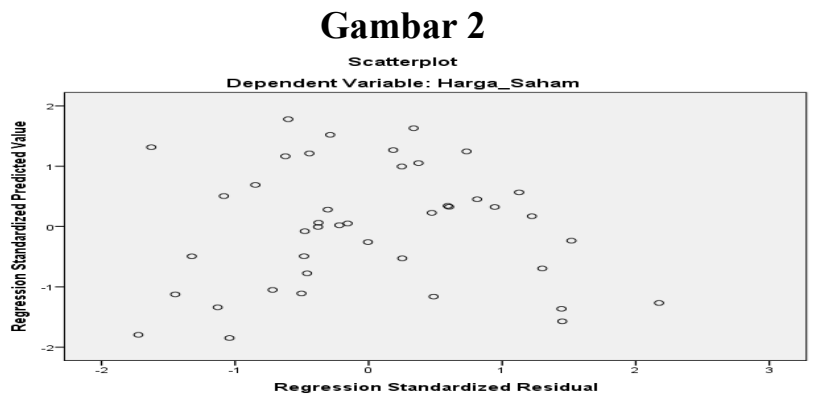

Dari output di atas dapat diketahui bahwa titik-titik tidak membentuk pola yang jelas, dan titik-titik menyebar diatas dan dibawah angka 0 pada sumbu Y, maka ini menunjukkan tidak terjadi heteroskedastisitas.

d. Uji Autokorelasi

Tabel 3

Model Summary

\begin{tabular}{|c|c|c|c|c|c|c|c|c|c|c|}
\hline \multirow[b]{2}{*}{ Model } & \multirow[b]{2}{*}{$\mathrm{R}$} & \multirow[b]{2}{*}{$\begin{array}{c}\mathrm{R} \\
\text { Square }\end{array}$} & \multirow[b]{2}{*}{$\begin{array}{l}\text { Adjusted } \\
\text { R Square }\end{array}$} & \multirow[b]{2}{*}{$\begin{array}{l}\text { Std. Error of } \\
\text { the Estimate }\end{array}$} & \multicolumn{5}{|c|}{ Change Statistics } & \multirow[b]{2}{*}{$\begin{array}{l}\text { Durbin- } \\
\text { Watson }\end{array}$} \\
\hline & & & & & $\begin{array}{l}\text { R Square } \\
\text { Change }\end{array}$ & $\begin{array}{c}\mathrm{F} \\
\text { Change }\end{array}$ & df1 & df2 & $\begin{array}{c}\text { Sig. F } \\
\text { Change }\end{array}$ & \\
\hline 1 & $.570^{\mathrm{a}}$ & .325 & .232 & .61766 & .325 & 3.473 & 5 & 36 & .012 & 2.171 \\
\hline
\end{tabular}

a. Predictors: (Constant), STA, RETA, MVE_BVL, EBITTA, WCTA

b. Dependent Variable: Harga_Saham 
Berdasarkan tabel di atas, diketahui nilai DW 2,171, nilai ini lebih dari satu atau lebih kecil dari tiga, maka dapat disimpulkan bahwa model regresi dalam penelitian tidak terjadi autokorelasi.

2) Uji Regresi Linier Berganda

a. Hasil Uji F

Tabel 4

ANOVA $^{\mathrm{a}}$

\begin{tabular}{|ll|r|r|r|r|r|}
\hline \multicolumn{1}{|l|}{ Model } & Sum of Squares & Df & Mean Square & F & Sig. \\
\hline 1 & Regression & 6.626 & 5 & 1.325 & 3.473 & $.012^{\mathrm{b}}$ \\
& Residual & 13.734 & 36 & .382 & & \\
& Total & 20.360 & 41 & & & \\
\hline
\end{tabular}

a. Dependent Variable: Harga_Saham

b. Predictors: (Constant), STA, RETA, MVE BVL, EBITTA, WCTA

Hasil pengujian uji $\mathrm{F}$ menunjukkan nilai signifikan yang diperoleh adalah 0,012. Karena nilai sig. lebih kecil dari 0,05 maka $\mathrm{H}_{0}$ ditolak dan $\mathrm{H}_{1}$ diterima sehingga dapat disimpulkan bahwa variabel Working Capital To Total Asset, Retained Earning To Total Asset, Earning Before Interest And Taxes, Market Value Of Equity To Book Value Liabilities dan Sales To Total Asset secara simultan berpengaruh terhadap variabel Harga Saham pada perusahaan manufaktur yang terdaftar di BEI periode 2014-2016.

b. Hasil Uji $t$

Tabel 5

Coefficients $^{2}$

\begin{tabular}{|c|c|c|c|c|c|c|}
\hline \multirow{2}{*}{\multicolumn{2}{|c|}{ Model }} & \multicolumn{2}{|c|}{$\begin{array}{c}\text { Unstandardized } \\
\text { Coefficients }\end{array}$} & \multirow{2}{*}{$\begin{array}{c}\text { Standardized } \\
\text { Coefficients } \\
\text { Beta } \\
\end{array}$} & \multirow[b]{2}{*}{$t$} & \multirow[b]{2}{*}{ Sig. } \\
\hline & & B & Std. Error & & & \\
\hline \multirow[t]{6}{*}{1} & (Constant) & 5.945 & .454 & & 13.090 & .000 \\
\hline & WCTA & .649 & .645 & .166 & 1.007 & .321 \\
\hline & RETA & .715 & .537 & .231 & 1.333 & .191 \\
\hline & EBITTA & 2.135 & 1.638 & .209 & 1.303 & .201 \\
\hline & MVE_BVL & -1.562 & .728 & -.310 & -2.146 & .039 \\
\hline & STA & .124 & .351 & .052 & .353 & .726 \\
\hline
\end{tabular}

a. Dependent Variable: Harga_Saham

Hasil pengujian uji t menunjukkan nilai signifikansi untuk setiap variabel independen. Dari hasil pengujian 5 variabel independen dapat diketahui bahwa :

1. Working Capital To Total Asset mempunyai nilai signifikansi sebesar 0,321, nilai ini lebih besar dari 0,05 sehingga Ho diterima, artinya Working Capital To Total Asset tidak berpengaruh terhadap Harga Saham.hal ini terjadi Kemungkinan dikarenakan banyaknya investor spekulan yang berinvestasi jangka pendek sehingga tidak melihat rasio Working Capital To Total Asset sehingga lebih memilih rasio keuangan yang lain untuk pertimbangan dalam pembelian saham

2. Retained Earning To Total Asset mempunyai nilai signifikansi sebesar 0,191, nilai ini lebih besar dari 0,05 sehingga Ho diterima, artinya Retained Earning To Total Asset tidak berpengaruh terhadap Harga Saham. Kemungkinan 
dikarenakan banyaknya investor spekulan yang berinvestasi jangka pendek sehingga tidak melihat rasio Retained Earning To Total Asset sehingga lebih memilih rasio keuangan yang lain untuk pertimbangan dalam pembelian saham.

3. Earning Before Interest And Taxes To Total Asset mempunyai nilai signifikansi sebesar 0,201, nilai ini lebih besar dari 0,05 sehingga Ho diterima, artinya Earning Before Interest And Taxes To Total Asset tidak berpengaruh terhadap Harga Saham. Kemungkinan dikarenakan banyaknya investor spekulan yang berinvestasi jangka pendek sehingga tidak melihat rasio Earning Before Interest And Taxes To Total Asset sehingga lebih memilih rasio keuangan yang lain untuk pertimbangan dalam pembelian saham.

4. Market Value Of Equity To Book Value Liabilities mempunyai nilai signifikansi sebesar 0,039, nilai ini kecil besar dari 0,05 sehingga Ho ditolak, artinya Market Value Of Equity To Book Value Liabilities berpengaruh terhadap Harga Saham. Hal ini berarti sesuai dengan teori yang menyatakan bahwa Market Value of Equity To Book Value Liabilities berpengaruh terhadap Harga Saham.

5. Sales To Total Asset mempunyai nilai signifikansi sebesar 0,726, nilai ini lebih besar dari 0,05 sehingga Ho diterima, artinya Sales To Total Asset tidak berpengaruh terhadap Harga Saham. Kemungkinan dikarenakan banyaknya investor spekulan yang berinvestasi jangka pendek sehingga tidak melihat rasio Sales To Total Asset sehingga lebih memilih rasio keuangan yang lain untuk pertimbangan dalam pembelian saham.

c. Uji Koefisien Determinasi $\left(\mathrm{R}^{2}\right)$

Tabel 6

Model Summary

\begin{tabular}{|c|c|c|c|c|c|c|c|c|c|c|}
\hline \multirow[b]{2}{*}{ Model } & \multirow[b]{2}{*}{$\mathrm{R}$} & \multirow[b]{2}{*}{$\begin{array}{c}\mathrm{R} \\
\text { Square }\end{array}$} & \multirow[b]{2}{*}{$\begin{array}{l}\text { Adjusted } \\
\text { R Square }\end{array}$} & \multirow[b]{2}{*}{$\begin{array}{l}\text { Std. Error of } \\
\text { the Estimate }\end{array}$} & \multicolumn{5}{|c|}{ Change Statistics } & \multirow[b]{2}{*}{$\begin{array}{l}\text { Durbin- } \\
\text { Watson }\end{array}$} \\
\hline & & & & & $\begin{array}{l}\text { R Square } \\
\text { Change }\end{array}$ & F Change & $d f 1$ & $d f 2$ & $\begin{array}{l}\text { Sig. F } \\
\text { Change }\end{array}$ & \\
\hline 1 & $.570^{\mathrm{a}}$ & .325 & .232 & .61766 & .325 & 3.473 & 5 & 36 & .012 & 2.171 \\
\hline
\end{tabular}

a. Predictors: (Constant), STA, RETA, MVE_BVL, EBITTA, WCTA

b. Dependent Variable: Harga_Saham

Dari tabel diatas menunjukkan bahwa 32,5 \% dari variabel perubahan Harga Saham dapat dijelaskan oleh variabel independennya. Sementara sisanya 67,5\% dapat dijelaskan oleh variabel lainya diluar variabel yang di teliti.

d. Persamaan Regresi

Tabel 7

\begin{tabular}{|c|c|c|c|c|c|c|c|c|}
\hline \multicolumn{9}{|c|}{ Coet } \\
\hline \multirow{2}{*}{\multicolumn{2}{|c|}{ Model }} & \multicolumn{2}{|c|}{$\begin{array}{c}\text { Unstandardized } \\
\text { Coefficients }\end{array}$} & \multirow{2}{*}{$\begin{array}{c}\begin{array}{c}\text { Standardized } \\
\text { Coefficients }\end{array} \\
\text { Beta }\end{array}$} & \multirow[b]{2}{*}{$\mathrm{t}$} & \multirow[b]{2}{*}{ Sig. } & \multicolumn{2}{|c|}{ Collinearity Statistics } \\
\hline & & B & Std. Error & & & & Tolerance & VIF \\
\hline \multirow[t]{6}{*}{1} & (Constant) & 5.945 & .454 & & 13.090 & .000 & & \\
\hline & WCTA & .649 & .645 & .166 & 1.007 & .321 & .690 & 1.448 \\
\hline & RETA & .715 & .537 & .231 & 1.333 & 191 & .624 & 1.602 \\
\hline & EBITTA & 2.135 & 1.638 & .209 & 1.303 & .201 & .729 & 1.372 \\
\hline & MVE_BVL & -1.562 & .728 & -.310 & -2.146 & .039 & .899 & 1.113 \\
\hline & STA & .124 & .351 & .052 & .353 & .726 & .867 & 1.154 \\
\hline
\end{tabular}

a. Dependent Variable: Harga_Saham 


$$
Y=5,945+0,649 X_{1}+0,715 X_{2}+2,135 X_{3}-1,562 X_{4}+0,124 X_{5}
$$

Jika nilai variabel Working Capital To Total Asset $\left(\mathrm{X}_{1}\right)$, Retained Earning To Total Asset ( $\left.\mathrm{X}_{2}\right)$, Earning Before Interest And Taxes To Total Asset $\left(\mathrm{X}_{3}\right)$, Market Value Of Equity To Book Value Liabilities $\left(\mathrm{X}_{4}\right)$ dan Sales To total Asset ( $\left.\mathrm{X}_{5}\right)$ dianggap sama dengan nol yang artinya tidak diperhitungkan, maka nilai variabel Harga Saham (Y) sebesar 5,945. Jika variabel $\mathrm{X}_{1}, \mathrm{X}_{2}, \mathrm{X}_{3}, \mathrm{X}_{4}$ dan $\mathrm{X}_{5}$ mengalami kenaikan sebesar satu satuan maka variabel $\mathrm{Y}$ akan mengalami kenaikan.Hal ini menunjukan bahwa variabel $\mathrm{X}_{1}, \mathrm{X}_{2}, \mathrm{X}_{3}, \mathrm{X}_{4}$ dan $\mathrm{X}_{5}$ mempengaruhi variabel $\mathrm{Y}$.

3) Uji Pengaruh Z-Score terhadap Harga Saham

a. Uji t

Tabel 10

Coefficients $^{a}$

\begin{tabular}{|c|c|c|c|c|c|c|}
\hline \multirow{2}{*}{\multicolumn{2}{|c|}{ Model }} & \multicolumn{2}{|c|}{$\begin{array}{c}\text { Unstandardized } \\
\text { Coefficients }\end{array}$} & \multirow{2}{*}{$\begin{array}{c}\text { Standardized } \\
\text { Coefficients } \\
\text { Beta } \\
\end{array}$} & \multirow[b]{2}{*}{$\mathrm{T}$} & \multirow[b]{2}{*}{ Sig. } \\
\hline & & $\mathrm{B}$ & Error & & & \\
\hline \multirow[t]{2}{*}{1} & (Constant) & 5.578 & .302 & & 18.476 & .000 \\
\hline & Z_Score & 1.034 & .336 & .438 & 3.078 & .004 \\
\hline
\end{tabular}

a. Dependent Variable: Harga_Saham

Hasil pengujian uji t menunjukkan nilai signifikansi untuk variabel independen. Dari hasil variabel independen dapat diketahui bahwa Z-Score mempunyai nilai signifikansi sebesar 0,04, nilai ini lebih kecil dari 0,05 sehingga Ho ditolak, artinya Z-Score berpengaruh terhadap Harga Saham. Hasil penelitian menunjukkan bahwa variabel Z-score berpengaruh terhadap Harga Saham pada perusahaan manufaktur yang terdaftar di BEI periode 2014-2016, hal ini berarti sesuai dengan teori yang menyatakan bahwa Z-score berpengaruh terhadap Harga Saham.

b. Uji Koefisien Determinasi $\left(\mathrm{R}^{2}\right)$

Tabel 11

Model Summary

\begin{tabular}{|c|c|c|c|c|c|c|c|c|c|c|}
\hline \multirow[b]{2}{*}{ Model } & \multirow[b]{2}{*}{$\mathrm{R}$} & \multirow[b]{2}{*}{$\begin{array}{c}\mathrm{R} \\
\text { Square }\end{array}$} & \multirow{2}{*}{$\begin{array}{c}\text { Adjusted } \\
\mathrm{R} \\
\text { Square }\end{array}$} & \multirow{2}{*}{$\begin{array}{l}\text { Std. Error } \\
\text { of the } \\
\text { Estimate }\end{array}$} & \multicolumn{5}{|c|}{ Change Statistics } & \multirow[b]{2}{*}{$\begin{array}{l}\text { Durbin- } \\
\text { Watson }\end{array}$} \\
\hline & & & & & $\begin{array}{l}\text { R Square } \\
\text { Change }\end{array}$ & $\begin{array}{c}\mathrm{F} \\
\text { Change }\end{array}$ & df1 & $\mathrm{df2}$ & $\begin{array}{c}\text { Sig. F } \\
\text { Change }\end{array}$ & \\
\hline 1 & $.438^{a}$ & .192 & .171 & .64088 & .192 & 9.477 & 1 & 40 & .004 & 1.986 \\
\hline
\end{tabular}

a. Predictors: (Constant), Z_Score

b. Dependent Variable: Harga_Saham

Dari tabel diatas menunjukkan bahwa 19,2 \% dari variabel perubahan Harga Saham dapat dijelaskan oleh variabel independennya. Sementara sisanya 80,8 \% dapat dijelaskan oleh variabel lainya diluar variabel yang di teliti.

4) PERBANDINGAN HASIL PENELITIAN DENGAN TEORI

Pengaruh Altman Z-Score (X) terhadap Harga Saham (Y) pada Perusahaan Manufaktur yang terdaftar di BEI Periode 2014-2016.

Hasil penelitian menunjukkan bahwa variabel Z-score berpengaruh terhadap Harga Saham pada perusahaan manufaktur yang terdaftar di BEI periode 2014-2016, hal ini berarti sesuai dengan teori yang menyatakan bahwa Z-score berpengaruh terhadap Harga Saham. 
Pengaruh Working Capital To Total Asset $\left(\mathrm{X}_{1}\right)$ terhadap Harga Saham (Y) pada perusahaan Manufaktur yang terdaftar di BEI periode 2014-2016.

Hasil penelitian menunjukkan bahwa variabel tidak berpengaruh Working Capital To Total Asset terhadap Harga Saham pada perusahaan manufaktur yang terdaftar di BEI periode 2014-2016, hal ini berarti tidak sesuai dengan teori yang menyatakan bahwa Working Capital To Total Asset berpengaruh terhadap Harga Saham. Kemungkinan dikarenakan banyaknya investor spekulan yang berinvestasi jangka pendek sehingga tidak melihat rasio Working Capital To Total Asset sehingga lebih memilih rasio keuangan yang lain untuk pertimbangan dalam pembelian saham.

Pengaruh Retained Earning To Total Asset $\left(\mathrm{X}_{2}\right)$ terhadap Harga Saham (Y) pada perusahaan Manufaktur yang terdatfar di BEI periode 2014-2016.

Hasil penelitian ini dapat disimpulkan bahwa tidak terdapat pengaruh antara Retained Earning To Total Asset terhadap Harga Saham pada perusahaan manufaktur yang terdaftar di BEI periode 2014-2016. Hal ini berarti tidak sesuai dengan teori yang menyatakan bahwa Retained Earning To Total Asset berpengaruh terhadap Harga Saham. Kemungkinan dikarenakan investor lebih menginginkan dividen atau laba yang dibagikan kepada pemegang saham lebih besar sehingga investor tidak melihat rasio Retained Earning To Total Asset untuk pertimbangan pembelian saham.

Pengaruh Earning Before Interest And Taxes To Total Asset $\left(\mathrm{X}_{3}\right)$ terhadap Harga Saham (Y) pada perusahaan Manufaktur yang terdatfar di BEI periode 2014-2016. Hasil penelitian ini dapat disimpulkan bahwa tidak terdapat pengaruh antara Earning Before Interest And Taxes To Total Asset terhadap Harga Saham pada perusahaan manufaktur yang terdaftar di BEI periode 2014-2016. Hal ini berarti tidak sesuai dengan teori yang menyatakan bahwa Earning Before Interest And Taxes To Total Asset berpengaruh terhadap Harga Saham. Kemungkinan dikarenakan banyaknya investor spekulan yang berinvestasi jangka pendek sehingga tidak melihat rasio Earning Before Interest And Taxes To Total Asset sehingga lebih memilih rasio keuangan yang lain untuk pertimbangan dalam pembelian saham.

Pengaruh Market Value Of Equity To Book Value Liabilities $\left(\mathrm{X}_{4}\right)$ terhadap Harga Saham (Y) pada perusahaan Manufaktur yang terdatfar di BEI periode 2014-2016. Hasil penelitian ini dapat disimpulkan bahwa terdapat pengaruh antara Market Value Of Equity To Book Value Liabilities terhadap Harga Saham pada perusahaan manufaktur yang terdaftar di BEI periode 2014-2016. Hal ini berarti sesuai dengan teori yang menyatakan bahwa Market Value Of Equity To Book Value Liabilities berpengaruh terhadap Harga Saham.

Pengaruh Sales To Total Asset $\left(\mathrm{X}_{5}\right)$ terhadap Harga Saham (Y) pada perusahaan Manufaktur yang terdatfar di BEI periode 2014-2016.

Hasil penelitian ini dapat disimpulkan bahwa tidak terdapat pengaruh antara Sales To Total Asset terhadap Harga Saham pada perusahaan manufaktur yang terdaftar di BEI periode 2014-2016. Hal ini berarti tidak sesuai dengan teori yang menyatakan bahwa Sales To Total Asset berpengaruh terhadap Harga Saham. Kemungkinan dikarenakan banyaknya investor spekulan yang berinvestasi jangka pendek sehingga tidak melihat rasio Sales To Total Asset sehingga lebih memilih rasio keuangan yang lain untuk pertimbangan dalam pembelian saham. 
Pengaruh Working Capital To Total Asset, Retained Earning To Total Asset, Market Value Of Equity To Book Value Liabilities dan Sales To Total Asset terhadap Harga Saham Pada Perusahaan Manufaktur yang terdaftar di BEI periode 2014-2016

Hasil penelitian menunjukkan nilai signifikan yang diperoleh adalah 0,012 , hal ini berarti secara simultan variabel Working Capital To Total Asset, Retained Earning To Total Asset, Earning Before Interest And Taxes To Total Asset, Market Value Of Equity To Book Value Liabilities dan Sales To Total Asset berpengaruh terhadap Harga Saham Pada Perusahaan manufaktur yang terdaftar di BEI periode 2014-2016.

\section{KESIMPULAN}

Berdasarkan hasil pengolahan data sebelumnya dan analisa hasil maka bisa disimpulkan sebagai jawaban dari perumusan masalah dalam penelitian ini adalah sebagai berikut :

1. Variabel Working Capital To Total Asset tidak berpengaruh terhadap Harga Saham pada perusahaan manufaktur yang terdaftar di BEI periode 2014-2016.

2. Variabel Retained Earning To Total Asset tidak berpengaruh terhadap Harga Saham pada perusahaan manufaktur yang terdaftar di BEI periode 2014-2016.

3. Variabel Earning Before Interest And Taxes To Total Asset tidak berpengaruh terhadap Harga Saham pada perusahaan manufaktur yang terdaftar di BEI periode 2014-2016.

4. Variabel Market Value Of Equity To Book Value Liabilities berpengaruh terhadap Harga Saham pada perusahaan manufaktur yang terdaftar di BEI periode 2014-2016.

5. Variabel Sales To Total Asset tidak berpengaruh terhadap Harga Saham pada perusahaan manufaktur yang terdaftar di BEI periode 2014-2016.

6. Variabel Working Capital To Total Asset, Retained Earning To Total Asset, Earning Before Interest And Taxes To Total Asset, Market Value Of Equity To Book Value Liabilities dan Sales To Total Asset secara simultan berpengaruh terhadap Harga Saham pada perusahaan manufaktur yang terdaftar di BEI periode 2014-2016.

7. Variabel Z-Score berpengaruh terhadap Harga Saham pada perusahaan manufaktur yang terdaftar di BEI periode 2014-2016.

\section{DAFTAR PUSTAKA}

Agus Harjito dan Martono. 2011. Manajemen Keuangan. Edisi Kedua. Cetakan Pertama. Yogyakarta: Penerbit EKONISIA

Agus Sartono. 2014. Manajemen Keuangan Teori dan Perencanaan keuangan Perusahaan. Jakarta. PT. Gramedia Pustaka Utama.

Andromeda Ardian. 2014. "Pengaruh Analisis Kebangkrutan Model Altman Z-score Terhadap Harga saham perusahaan Manufaktur Periode 2008-2013".

Angga Saputra. 2013. "Pengaruh Kebangkrutan Perusahaan Dengan Model Altman Z-score Terhadap Harga Saham Perusahaan Consumer Goods Industry Yang Tercatat Di BEI Tahun 2010-2012".

Azwar Syarifuddin. 2013. Metode Penelitian. Yogyakarta: Pustaka Pelajar.

Bambang Sumardjoko. 2011. Metode Statistik. Jakarta: Badan Penerbit-FKIP UMS

Darsono dan Ashari. 2010. Pedoman Praktis Memahami Laporan Keuangan.Yogyakarta: Penerbit ANDI.

Dewi Sukmawati. 2014. "Pengaruh Rasio-rasio Dalam Model Altman Z-score Terhadap Harga saham Perusahaan Perbankan Yang Terdaftar Di BEI Tahun 2012”.

Ghozali Imam. 2011, Aplikasi Analisis Multivariate dengan Program SPSS, Badan Penerbit Universitas Diponegoro.

Gumanti, Tatang. 2011. Manajemen Investasi : Konsep, Teori, dan Aplikasi. Edisi Pertama. Jakarta : Mitra Wacana Media. 
Hery. 2012. Analisis Laporan Keuangan. Jakarta: Bumi Aksara. Irham Fahmi. 2013. Analisis Laporan Keuangan. Bandung: Alfabeta.

Jogiyanto. 2015. Teori Portofolio dan Analisis Investasi. Edisi Ketiga. Yogyakarta: BPFEYogyakarta.

Kusuma Putra. 2016. "Pengaruh Analisis Kebangkrutan Perusahaan Terhadap Harga Saham Dengan Model Altman Z-score Pada Perusahaan Komponen Dan Otomotif Yang Terdaftar Di BEI Tahun 2010-2014".

L. M. Samryn. 2011. Pengantar Akuntansi. Edisi Pertama. Jakarta. Penerbit Raja Grafindo Persada.

Mario Wasono. 2012. "Pengaruh Financial Distress Ratio Model Altman Terhadap Harga Saham Dengan Model Altman Z-score Pada Perusahaan Manufaktur Yang Terdaftar Di BEI Tahun 2008-2010

M.Hanafi dan Abdul Halim. 2016. Analisis Laporan Keuangan. Edisi Kelima. Cetakan Pertama. Yogyakarta: Penerbit UPP STIM YKPN.

Sedarmayanti dan Hidayat, Syarifudin. 2011. Metodologi Penelitian. Bandung: Mandar Maju.

Singgih Santoso. 2014. Panduan Lengkap SPSS Versi 20 Edisi Revisi. Jakarta: Gramedia.

Sofyan Syafri Harahap. 2011. Analisis Kritis Atas Laporan Keuangan. Jakarta: Raja grafindo Persada.

Suad Husnan, 2016. Teori Portofolio dan Analisis Sekurita. Edisi Keempat. Yogyakarta. UPP STIM YKPN.

Sugiono. 2011. Metode Penelitian Kuantitatif, Kualitatif dan R\&D. Bandung: ALFABETA

Sunariyah. 2011. Pengantar Pengetahuan Pasar Modal. Edisi Keenam. Yogyakarta: UPP STIM YKPN.

Toto Prihadi. 2011. Analisis Laporan Keuangan Teori dan Aplikasi. Jakarta: Penerbit PPM.

Vidya Saputra. 2015. “Analisis Kebangkrutan Dengan Model Altman Z-score Dan Pengaruhnya Terhadap Harga Saham Perusahaan Jasa Sektor Telekomunikasi Yang Terdaftar Di BEI". 